\title{
THE SURVIVING CROSSOPTERYGIAN FISH, LATIMERIA
}

\section{By Sir Arthur Smith Woodward, F.R.S.}

$I^{N}$ Nature of May 6, 1939, p. 455, Prof. J. L. B. Smith, of Rhodes University College, Grahamstown, announced the discovery in South African seas of a living Crossopterygian or paddle-finned fish. He recognized that it belonged to the group of Coelacanths, which was known only by fossils and was supposed to have been extinct since the end of the Cretaceous period. In the Transactions of the Royal Society of South Africa, he now describes in detail the remains of this fish*. Unfortunately, there are no more than dried remains ; for when the specimen was sent to the East London Museum its scientific value was not appreciated, and it was entrusted to a taxidermist, who preserved little beyond the external parts and damaged some of these by piercing them with pins and nails. Prof. Smith laments his "relatively crude equipment" for dealing with the fish, but he is to be congratulated on his laborious effort and on the technical account of so much as he has been able to observe. His memoir is illustrated by an exhaustive series of photographs and a few diagrammatic text-figures. There is also an explanatory list of the numerals and letters used in all the illustrations, and this is arranged on a page which unfolds outwards so that it may be kept always in view.

The Coelacanths have changed very little since their first known appearance in Upper Devonian formations, and it is difficult to separate the new living fish from some of the old genera which are represented by fossils. For convenient reference, however, Prof. Smith has done well to give this fish a new generic name, Latimeria, which commemorates Miss Courtenay Latimer, the curator of the East London Museum. Very curiously, it retains the complete supplementary tail fin which characterizes the Jurassic and earlier genera, and thus differs from the latest or Cretaceous genera, Macropoma and Mawsonia, which have the tail extension reduced and lacking fin rays. Only the anterior dorsal fin, with its eight strong rays armed with upwardly pointing denticles, and the scales with their sharp denticles, are specially like those of Macropoma. The caudal fin seems to have a few more rays than any of the known extinct genera.

As in all Coelacanths, there are no scales on the head, and the sensory canals are conspicuous. The circumorbital plates, so commonly observed

"J. L. B. Smith, "A Living Coelacanthid Fish from South Africa", Trans. Roy. Soe. S. Africa, 28, Pt. 1, 1-106, pls. i-xliv, 1939 (received April 1940). in Coelacanths, are absent. The two nostrils are well seen on each side of the snout, but Prof. Smith has been able to dissect this region and he thinks that they do not communicate direct with the olfactory capsules. These capsules are described as situated on either side of a large median chamber, which he names "ethmoidal nasal cavity" ; and the cavity is said to be connected by tubes both with the two pairs of external nostrils and with a pair of openings on the front end of the snout. The remarkable arrangement needs further study in a better preserved specimen. The cranium, indeed, is so much damaged that Prof. Smith has been able to observe very little of it.

There is nothing unusual in the external bones of the head, but, as already suspected, it is now clear that the preoperculum is extended on the cheek as in the early Chondrosteans. There are also degenerate remnants of the suboperculum and interoperculum. The mouth is very interesting. because, although there is no bony maxilla, this element is represented by "a thickened fold of skin" which bears the usual little tooth-plates or clusters of conical teeth. Especially important and new is the identification of the hyomandibular bone, which is described as "very firmly bound to the inner face of the anterior margin of the opercular". It is ossified only in its middle por. tion, the long ends remaining cartilaginous. From the hyomandibular there extends downwards and forwards a relatively large symplectic bone, which articulates with a hollow facet on the articular bone of the lower jaw, well behind the quadrate articulation. As Prof. Smith remarks, the arrangement is suggestive of that in the existing Chondrosteans. He points out that the facet on the articular bone has already been shown in published drawings of the lower jaw of the Devonian coelacanth Diplocercides; and he might have added that a pit in the same position has been described in the lower jaw of the Cretaceous Macropoma and Mawsonia.

The spiracle is supposed to have been functionless, but this portion of the head is badly preserved. The gill arches were destroyed, but the copula seems to show that there were only four pairs. Five pairs have been seen in some of the extinct Coelacanths.

The internal parts of the dried body have been so completely removed that little remains even of the skeleton. One hæmal spine in the tail, however, 
is seen to consist chiefly of cartilage surrounded by a thin cylinder of bone, thus exhibiting the structure to which the name Coelacanth (hollow spine) refers, for the cartilage disappears and leaves a hollow space in the fossils.

The only new character described in the fins is the extension backwards of the membrane of the anterior dorsal fin beyond its eight rays. The extension is low and rapidly tapers behind, without any skeletal stiffening. The scales appear normal, and Prof. Smith observes ring-markings which he thinks prove the age of the fish to be between twenty and twenty-five years.
The exceptionally oily nature of Latimeria, already mentioned in the preliminary notice, is interesting geologically, because it indicates one possible source of the oil in many stratified rocks. Like most of the extinct Coelacanths, there is no doubt that it is a sea fish, not a straggler from a river. As Prof. Smith remarks, however, the annulation of the scales shows that it cannot be a denizen of the ocean depths. It must be well within reach of the ordinary fishermen, and the interest now aroused should induce the trawlers off the east coast of South Africa to save any more specimens which they may find.

\section{O B I T U A R I E S}

Sir James Baillie, O.B.E.

GIR JAMES BLACK BAILLIE, who died on June 9 at the age of sixty-seven, was vice-chancellor of the University of Leeds from 1924 until 1938. A Scotsman, he was educated at the Universities of Edinburgh, Cambridge, Halle, Strasbourg, and Paris. At Edinburgh he had a particularly distinguished record, gaining the Ferguson scholarship and Shaw fellowship in philosophy, both open to graduates of the four Scottish universities. After graduation he was an assistant at the University of St. Andrews. Later he was lecturer in philosophy at University College, Dundee. He was professor of moral philosophy at the University of Aberdeen during 190224. He was knighted in 1931.

The most significant period of Baillie's life was when he was vice-chancellor at Leeds. He was keenly interested in problems of administration, and at Leeds this interest was fully satisfied. The University of Leeds saw great developments under his leadership. In 1925 an appeal was made by the University for the sum of half a million pounds for the purpose of erecting more adequate buildings. This appeal had realized about $£ 700,000$ at the time of his retirement, and many fine buildings had been erected, notably the Brotherton Library. Five new chairs and many lectureships and scholarships were instituted during Baillie's period of office, and valuable benefactions received. But human life is not merely thought or intellect in a narrow sense, as he himself showed in his "Studies in Human Nature" ; there are other highly important activities. So Baillie did not forget, for example, the athletic and social sides of university life. Playing fields were developed at a cost of more than $£ 50,000$ and a beginning was also made with a new Students' Union, which has recently been completed.

In his administrative work. Baillie showed great tenacity of purpose. He had the mind of an arbitrator, and indeed, both during the War of 1914-18 and since, he served in the capacity of arbitrator on several important Government com- missions. His attitude of mind and methods were perhaps sometimes rather cold and impersonal. He had weighed the pros and cons, he had come to a conclusion, he must give effect to the conclusion for the conclusion's sake. But there was a warm and sympathetic side to Baillie's nature. He was an excellent host to a wide circle of friends and he was a good conversationalist and a good listener.

Baillie's main philosophical interest was Hegelianism. In 1901 he published a commentary, "The Origin and Significance of Hegel's Logic". His "Outline of the Idealistic Construction of Experience", 1906 , is avowedly based on Hegel's. "Phänomenologie des Geistes". Perhaps Baillie's most important contribution to philosophy was his translation, with an introduction and notes, of the "Phänomenologie". It appeared in 1910 and in a second edition, with a much improved text, in 1931. Its first appearance was particularly notable, for here was a major work of Hegel's made available in English for the first time. In 1924 Baillie was a contributor to the first series of "Contemporary British Philosophy", a collection of personal statements by leading philosophers, edited by J. H. Muirhead. He was also a contributor to Hastings' "Encyclopædia of Religion and Ethics", the Hibbert Journal, Mind, and other periodicals. As a philosopher Baillie was an ingenious and acute dialectician. He was, too, a most stimulating lecturer, illuminating his theme from all sides of human nature. In many respects his outlook was not unlike that of his illustrious predeccssor, Thomas Reid, expounder of common sense. W. M. Dickre.

\section{Prof. Giuseppe Sanarelli}

Prof. Gruseppe Sanarelli, the eminent Italian hygienist, whose death occurred recently, was born on September 24, 1865, at Monte San Savino, Arexzo. $\mathrm{He}$ studied medicine at Siena, Pavia, under Golgi, Munich under Pettenkofer, and Paris under Pasteur, and qualified in 1889 at Siena, where he began his 